\title{
60. DATA REPORT: X-RAY MINERALOGY DATA FROM KERGUELEN PLATEAU, LEG 120, SITE $751^{1}$
}

\author{
James R. Breza ${ }^{2}$
}

\section{INTRODUCTION}

The purpose of this paper is to present data from a clay mineralogy investigation of the sediments analyzed for ice-rafted debris (IRD) from Hole 751A (see Breza, this volume). This data is significant in that the change in clay mineralogy may provide information about the Neogene evolution of climate and oceanic circulation near the Kerguelen Plateau and adjacent to Prydz Bay, Antarctica.

Site 751 is located in the central part of the Raggatt Basin on the Southern Kerguelen Plateau in $1633.8 \mathrm{~m}$ of water $\left(57^{\circ} 43.56^{\prime} \mathrm{S}\right.$, $79^{\circ} 48.89^{\prime} \mathrm{E}$ ) (Fig. 1). The plateau is a structural high isolated from any continental input by means of turbidities or nepheloid transport. It is bounded to the northeast by the Australian-Antarctic Basin, to the southwest by the African-Antarctic Basin, and to the northwest by the Crozet Basin. To the south it is separated from Antarctica by the Princess Elizabeth Trough.

Site 751 consists of two lithologic units (Fig. 2). Unit I is composed of $40 \mathrm{~m}$ of upper Pleistocene to lower Pliocene diatom ooze with varying amounts of IRD and foraminifers. Unit II consists of $126 \mathrm{~m}$ of upper to lower Miocene diatom nannofossil ooze, with nannofossils as the primary sedimentary component.

\section{METHODS}

Mineral identification of the $<2-\mu \mathrm{m}$ fraction was performed on $10-\mathrm{cm}^{3}$ samples collected from Hole 751A during Ocean Drilling Program (ODP) Leg 120. These samples were routine samples collected at a frequency of $2-3$ per section. The qualitative X-ray mineralogy results of this study are summarized in Table 1.

Samples were disaggregated by soaking them in distilled water for $24 \mathrm{hr}$. They were then dried, weighed, and washed through 250 - and a $62-\mu \mathrm{m}$ sieves using distilled water. The $\geq 62-\mu \mathrm{m}$ fraction was retained for clastic material identification as part of an ice-rafted debris study of the Kerguelen Plateau (see Breza, this volume). The $<62-\mu \mathrm{m}$ fraction was leached in $0.2 \mathrm{~N}$ hydrochloric acid. The excess acid was removed by repeated centrifugation followed by homogenization. The $<2-\mu \mathrm{m}$ size fraction was settled according to Stoke's Law and extracted with a pipette from the deflocculated sample using the standard settling method (Folk, 1980).

The extracts were mounted on petrographic slides using a modification of Pollastro's (1982) filter membrane technique (Holmes, 1989). A $0.45-\mu \mathrm{m}$-opening membrane filter was placed on a glass frit mount and placed over a suction flask. The pipetted sample was added to the flask and suction was applied to force the sample onto the filter membrane. The filter membrane was then placed upside down on a petrographic slide, pressure applied,

${ }^{1}$ Wise, S. W., Jr., Schlich, R., et al., 1992. Proc. ODP, Sci. Results, 120: College Station, TX (Ocean Drilling Program).

${ }^{2}$ Department of Geology, Florida State University, Tallahassee, FL 32306,

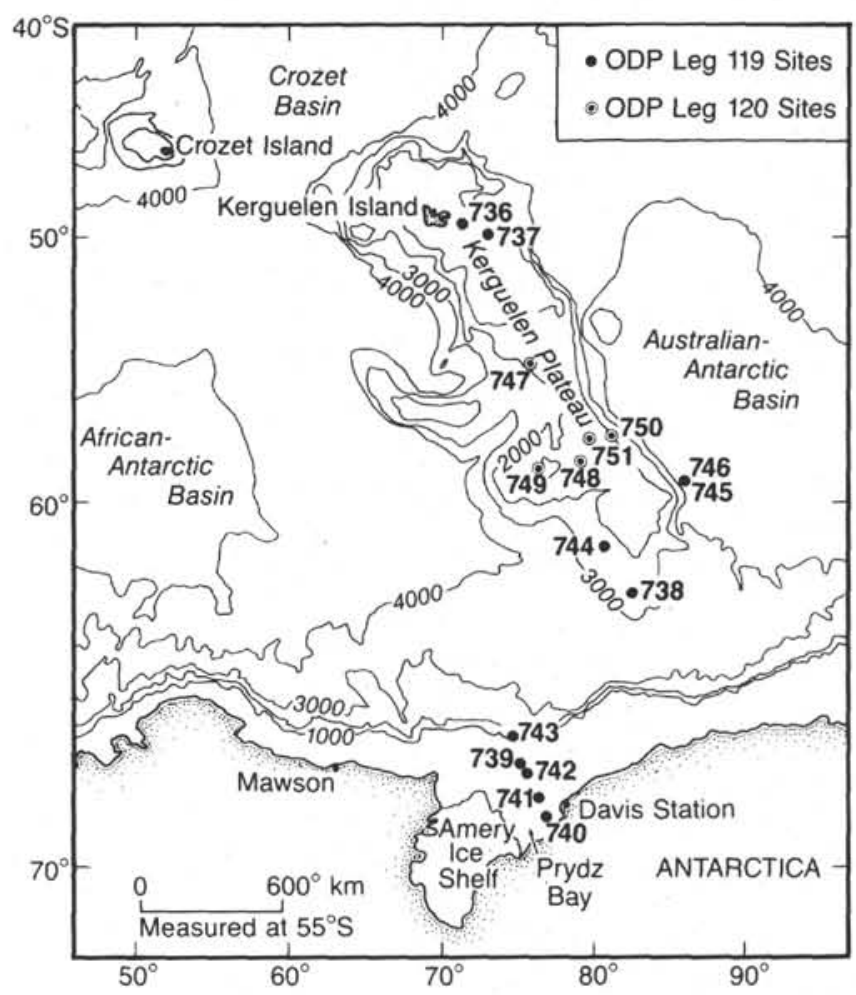

Figure 1. Bathymetric chart of the Kerguelen Plateau showing the Leg 120 site locations. The contour interval is $1000 \mathrm{~m}$.

and the filter membrane removed, leaving the extract adhered to the petrographic slide.

Two X-ray diffractograms (XRDs) were made of the oriented mounts: (1) an untreated sample X-rayed from $2^{\circ}$ to $40^{\circ} 2 \theta$, and (2) a sample (treated with ethylene glycol for more than $24 \mathrm{hr}$ at room temperature) $\mathrm{X}$-rayed from $2^{\circ}$ to $20^{\circ} 2 \theta$. A Philips diffractometer equipped with cobalt radiation and a receiving slit of $1 / 4^{\circ}$ was used at a scan speed of $1 \% \mathrm{~min}$.

The procedures for mineral identification followed those outlined by Brown and Brindley (1980). Smectite was identified from a peak at approximately $15 \AA$, which shifted to approximately 17 $\AA$ upon glycolation. Illite was identified from an approximate 10-A peak, which did not shift upon glycolation. A 7- $\AA$ mineral was also identified; however, no attempt was made to differentiate this mineral between chlorite and kaolinite, which both have $7-\AA$ peaks. The assumption was made that the minerals present when a 7- $\AA$ diffraction peak occurred were either chlorite and/or kaolinite. Figure 3 is a representative diffractogram of smectite, illite, and chlorite and/or kaolinite. An amorphous peak was also detected in most diffractograms. This peak is identified by a large diffuse broad silica peak occurring between $20^{\circ}$ and $25^{\circ} 2 \theta$ (Fig. 4). The amorphous content largely consist of biogenic silica. 


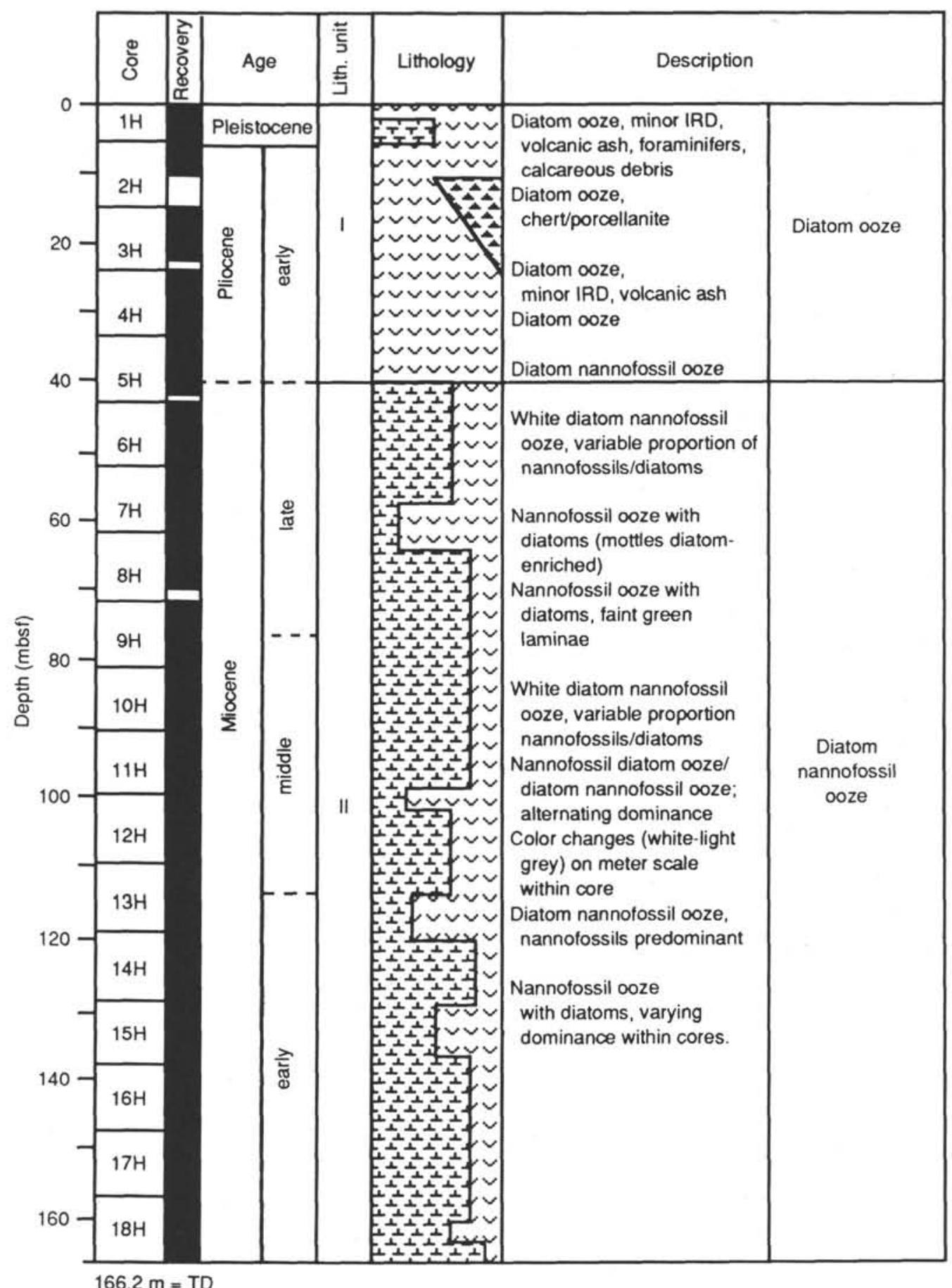

Figure 2. Lithostratigraphy of Site 751, Raggatt Basin, Southern Kerguelen Plateau. Recovered intervals indicated by shading in recovery column. For key to patterns in lithology column, see Schlich, Wise, et al. (1990, "Explanatory Notes" chapter). Figure from Schlich, Wise, et al. (1990). IRD = ice-rafted debris and TD = total depth.

\section{RESULTS}

The results of this clay mineralogy study are presented in a qualitative occurrence format in Table 1. However, because of the small amount of $<2-\mu \mathrm{m}$ size material available for X-ray analyses, the concentration of some crystalline minerals may not have been sufficient for the XRD to detect their presence.

\section{ACKNOWLEDGMENTS}

The author is grateful to Dennis Cassidy and Ami Kaharoeddin of the Antarctica Research Facility (FSU) for laboratory support. Many thanks are owed to Neill Vaughan (FSU) for preparing the samples. Thanks are also owed to Charlotte Kelley, who kindly assisted in editing the manuscript. Laboratory support was 


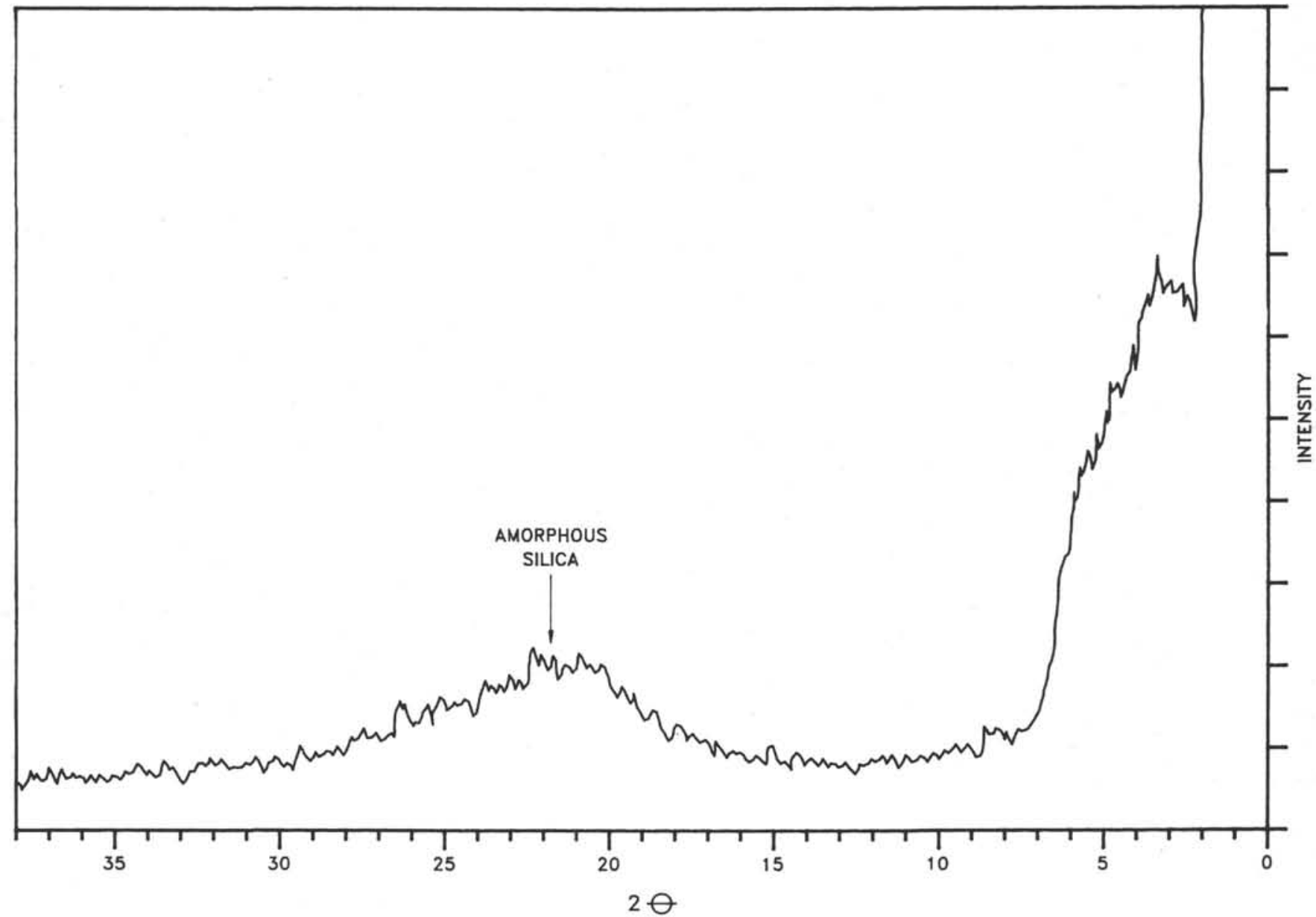

Figure 3. X-ray diffractogram for untreated clay fraction from Sample 120-751A-2H-2, 23-25 cm. S = smectite, I = illite, C/K= chlorite and/or kaolinite. The $x$-axis is ${ }^{\circ} 2 \theta$, and the $y$-axis is intensity.

provided by National Science Foundation Grant No. DPP8917976 and USSAC funds.

\section{REFERENCES}

Brown, G., and Brindley, G. W., 1980. X-ray diffraction procedures for clay mineral identification. In Brindley, G. W., and Brown, G. (Eds.), Crystal Structures of Clay Minerals and Their X-ray Identification. London Mineral. Soc. Monogr., 5:305-360.

Folk, R. L., 1980. Petrology of Sedimentary Rocks: Austin, TX (Hemphill Publ.).

Holmes, M. A., 1989. Lateral distribution of detrital clay minerals in Lower Cretaceous sediment, western North Atlantic and its continental margin [Ph.D. dissert.]. Florida State Univ., Tallahassee.
Pollastro, R. M., 1982. A recommended procedure for the preparation of oriented clay-mineral specimens for X-ray diffraction analysis: modifications to Drever's filter-membrane peel technique. Open-File Rep., U.S. Geol. Surv., 82-71.

Schlich, R., Wise, S. W., Jr., et al., 1990. Proc. ODP, Init. Repts., 120: College Station, TX (Ocean Drilling Program).

Date of initial receipt: 28 June 1990

Date of acceptance: 12 November 1990 Ms 120B-135 


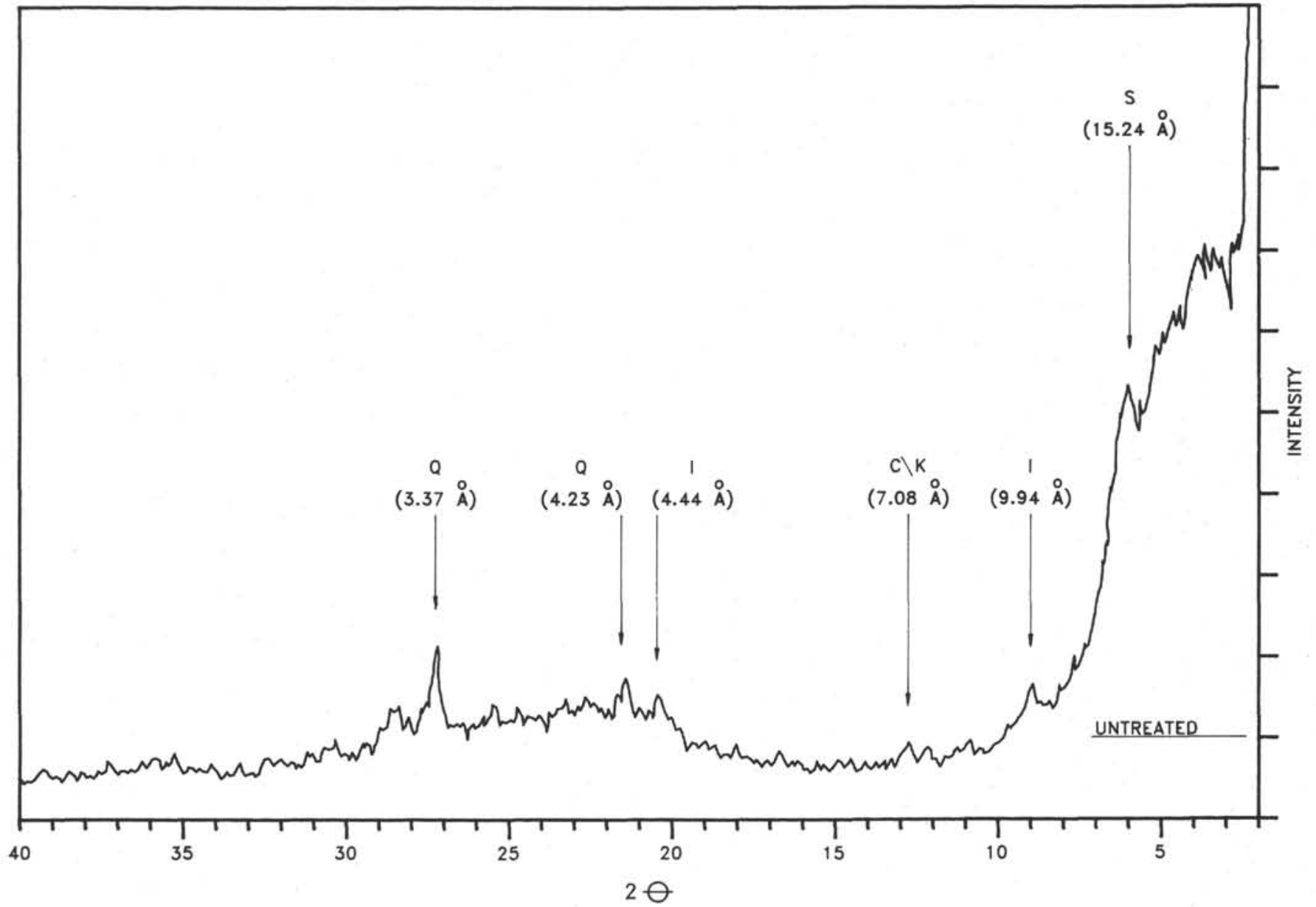

Figure 4. X-ray diffractogram for untreated clay fraction from Sample $120-751 \mathrm{~A}-7 \mathrm{H}-5,83-85 \mathrm{~cm}$. The $x$-axis is ${ }^{\circ} 2 \theta$, and the $y$-axis is intensity. 
Table 1. Results of X-ray diffraction analysis from Hole 751A.

\begin{tabular}{|c|c|c|c|c|c|}
\hline $\begin{array}{l}\text { Core, section, } \\
\text { interval }(\mathrm{cm})\end{array}$ & $\begin{array}{l}\text { Depth } \\
\text { (mbsf) }\end{array}$ & Smectite & Illite & $\begin{array}{l}\text { Chlorite/ } \\
\text { kaolinite }\end{array}$ & $\begin{array}{l}\text { Amorphous } \\
\text { silica }\end{array}$ \\
\hline
\end{tabular}

$$
\text { 120-751A- }
$$

1H-1, 23-

$1 \mathrm{H}-1,63-65$

$1 \mathrm{H}-1,123-125$

0.23

$1 \mathrm{H}-1,123-125$

$1 \mathrm{H}-2,79-8$

IH-2, 140-142 2.90

iH $-3,97-99 \quad 3.97$

$1 \mathrm{H}-3,137-139 \quad 4.37$

$2 \mathrm{H}-1,23-25 \quad 4.93$

$2 \mathrm{H}-1,63-65$

2H-1, 123-125 5.93

$2 \mathrm{H}-2,23-25 \quad 6.43$

$2 \mathrm{H}-2,63-65 \quad 6.83$

$2 \mathrm{H}-2,142-145 \quad 7.62$

$3 \mathrm{H}-1,63-65$

$3 \mathrm{H}-2,23-25$

$3 \mathrm{H}-2,83-85$

$3 \mathrm{H}-2,123-125-16.93$

$3 \mathrm{H}-3,63-65 \quad 17.83$

$3 \mathrm{H}-3,123-125 \quad 18.43$

$3 \mathrm{H}-4,23-25 \quad 18.93$

$3 \mathrm{H}-4,83-85 \quad 19.53$

$3 \mathrm{H}-4,103-105 \quad 19.73$

$3 \mathrm{H}-5,23-25 \quad 20.43$

3H-5, 83-85 21.03

$3 \mathrm{H}-5,142-145 \quad 21.62$

$4 \mathrm{H}-2,83-85 \quad 26.03$

$4 \mathrm{H}-2,142-145 \quad 26.62$

$4 \mathrm{H}-3,63-65 \quad 27.33$

$4 \mathrm{H}-3,123-125 \quad 27.93$

$4 \mathrm{H}-4,23-25 \quad 28.43$

$4 \mathrm{H}-4,83-85 \quad 29.03$

$4 \mathrm{H}-4,142-144 \quad 29.62$

$4 \mathrm{H}-5,63-65 \quad 30.33$

$4 \mathrm{H}-5,142-144 \quad 31.12$

$4 \mathrm{H}-6,23-25 \quad 31.43$

$4 \mathrm{H}-6,83-85$

$4 \mathrm{H}-6,142-144 \quad 32.62$

SH-1, 63-65 33.82

$5 \mathrm{H}-1,123-125 \quad 34.43$

$5 \mathrm{H}-2,23-25 \quad 34.93$

$5 \mathrm{H}-2,83-85 \quad 35.53$

SH-2, 142-144 36.12

5H-3, 63-65 36.83

$5 \mathrm{H}-3,123-125 \quad 37.43$

$5 \mathrm{H}-4,23-25 \quad 37.93$

$5 \mathrm{H}-4,83-85 \quad 38.53$

$5 \mathrm{H}-4,142-144 \quad 39.12$

$5 \mathrm{H}-5,63-65 \quad 39.83$

SH-5, 123-125 $\quad 40.43$

$5 \mathrm{H}-6,23-25 \quad 40.93$

$6 \mathrm{H}-1,83-85$

$6 \mathrm{H}-1,142-144 \quad 44.12$

$6 \mathrm{H}-2,63-65 \quad 44.83$

$6 \mathrm{H}-2,103-105 \quad 45.23$

$6 \mathrm{H}-3,23-25 \quad 45.93$

$6 \mathrm{H}-3,83-85 \quad 46.53$

$6 \mathrm{H}-3,142-144 \quad 47.12$

$6 \mathrm{H}-4,63-65 \quad 47.83$

$6 \mathrm{H}-5,23-25 \quad 48.93$

$6 \mathrm{H}-5,83-85 \quad 49.5$

$6 \mathrm{H}-5,142-144 \quad 50.12$

$6 \mathrm{H}-6,63-65 \quad 50.83$

$6 \mathrm{H}-6,123-125 \quad 51.43$

$6 \mathrm{H}-7,23-25 \quad 51.93$

7H-1, 83-85 53.03

$7 \mathrm{H}-1,142-144 \quad 53.62$

7H-2, 63-65 54.33

$7 \mathrm{H}-2,103-105 \quad 54.73$

$7 \mathrm{H}-3,23-25 \quad 55.43$

$7 \mathrm{H}-4,63-65 \quad 57.33$

7H-5, 23-25 58.43

7H-5, 83-85
Table 1 (continued).

\begin{tabular}{|c|c|c|c|c|c|}
\hline $\begin{array}{l}\text { Core, section, } \\
\text { interval }(\mathrm{cm})\end{array}$ & $\begin{array}{l}\text { Depth } \\
\text { (mbsf) }\end{array}$ & Smectite & Illite & $\begin{array}{l}\text { Chlorite/ } \\
\text { kaolinite }\end{array}$ & $\begin{array}{c}\text { Amorphous } \\
\text { silica }\end{array}$ \\
\hline \multicolumn{6}{|l|}{ 120-751A- (Cont.) } \\
\hline $8 \mathrm{H}-3,83-85$ & 65.53 & - & - & - & $\mathrm{X}$ \\
\hline $8 \mathrm{H}-4,103-105$ & 67.23 & - & - & - & $\mathrm{X}$ \\
\hline $8 \mathrm{H}-5,23-25$ & 67.93 & $\mathrm{x}$ & - & - & $\mathrm{X}$ \\
\hline $8 \mathrm{H}-5,83-85$ & 68.53 & - & - & - & $\mathrm{x}$ \\
\hline $8 \mathrm{H}-5,142-144$ & 69.12 & - & - & - & $\mathrm{X}$ \\
\hline $9 \mathrm{H}-1,23-25$ & 71.43 & - & - & - & $\mathrm{x}$ \\
\hline $10 \mathrm{H}-1,83-85$ & 81.53 & - & - & - & $\mathrm{X}$ \\
\hline $10 \mathrm{H}-1,142-144$ & 82.12 & - & - & - & $\mathrm{x}$ \\
\hline $10 \mathrm{H}-2,123-125$ & 83.43 & - & - & - & $\mathrm{x}$ \\
\hline $10 \mathrm{H}-3,23-25$ & 83.93 & - & - & - & - \\
\hline $10 \mathrm{H}-3,83-85$ & 84.53 & - & - & - & $\mathrm{x}$ \\
\hline $10 \mathrm{H}-3,142-145$ & 85.12 & - & - & - & $\mathrm{X}$ \\
\hline $10 \mathrm{H}-4,63-65$ & 85.83 & - & - & - & $\mathrm{x}$ \\
\hline $10 \mathrm{H}-4,123-125$ & 86.43 & - & - & - & $\mathrm{x}$ \\
\hline $10 \mathrm{H}-5,23-25$ & 86.93 & - & - & - & $\mathrm{X}$ \\
\hline $10 \mathrm{H}-5,83-85$ & 87.53 & - & - & - & $\mathrm{X}$ \\
\hline $10 \mathrm{H}-5,142-144$ & 88.12 & - & - & - & $\mathrm{X}$ \\
\hline $10 \mathrm{H}-6,63-65$ & 88.83 & - & - & - & $\mathrm{X}$ \\
\hline $10 \mathrm{H}-6,123-125$ & 89.43 & - & - & - & $\mathrm{x}$ \\
\hline $10 \mathrm{H}-7,23-25$ & 89.93 & - & - & - & $\mathrm{X}$ \\
\hline
\end{tabular}

Notes: $\mathrm{X}=$ mineral present in the sample analyzed, $-=$ mineral not present in the sample analyzed. 